\title{
Social distributional aspect of penal actions
}

\author{
Valery Lapshin ${ }^{1}$, and Sergey Korneev ${ }^{1 *}$ \\ ${ }^{1}$ Academy of the Federal penitentiary service of Russia, 1 Sennaya str., Ryazan, 390000, Russia
}

\begin{abstract}
Criminal legislation of any state provided at the initial stages of its development for punishment as the only measure of criminal law influence on a person committing a socially dangerous act. Moreover, the types of punishment mainly boiled down to long periods of isolation of the convicted person from society: hard labor and imprisonment. Only in the middle of the twentieth century Russian legislation ensured the distinction between the categories of "criminal punishment" and "criminal liability", although the official definition has not yet been formulated. The main legally significant signs of criminal punishment as measures of state coercion and other measures implemented within the framework of criminal liability coincide, and therefore it is not possible to ensure a consistent legal differentiation of these categories. In addition, "other measures" of a criminal law nature are highlighted in the Russian criminal legislation, their essence is currently uncertain, since they apply to persons incapable of criminal responsibility (insane, some groups of minors), and persons convicted of a crime. Such terminological inconsistency creates problems in practical application of provisions of the criminal and penal legislation to ensure the correction of convicted person and the prevention of new crimes. Basing on the results of the study, it was proposed to divide the groups of measures that are implemented within the framework of criminal liability institutions and other measures of a criminal law nature. The former apply to persons convicted of a crime. "Other measures" are applied to persons incapable of criminal responsibility for a committed socially dangerous act due to a state of health or social and intellectual immaturity: irresponsible, mentally retarded, minors. This will provide the proper terminological distinction of the essence of legal categories and will allow identifying true goals of their application.
\end{abstract}

\section{Introduction}

The category of "penal action" has recently become the subject of many scientific studies. This is due to the use of legal terms having ambiguous meaning. So, the term "criminal punishment" has an official definition and is a measure of state coercion, including deprivation and legal restriction of convicted person. However, the Criminal Code of Russian Federation also uses other categories of the same type: "criminal liability", "other measures of a criminal legal nature", which are not formally defined in the law.

*Corresponding author: a.copytowa@yandex.ru 
Such ambiguity creates matters of both scientific and practical importance. The inconsistency of criminal law terms indicates the low quality of legislative technique for formulating provisions of criminal law. This leads to the necessity of introducing into the scientific circulation a general concept of "penal action" combining all of the above categories: punishment, criminal liability, other measures of a criminal law nature. In practice, this inconsistency creates significant difficulties in choosing specific criminal law measures applicable for restoring social justice and preventing commission of new crimes.

The purpose of the study is to determine the legal content and differentiation of such legal categories as: punishment, criminal liability, other measures of a criminal law nature, penal action. Achieving this goal will make it possible to formulate proposals for improving the Russian criminal law, to determine the standard legal measures applicable to various categories of citizens committing an act prohibited by the criminal law. To achieve this goal it is necessary to solve the following tasks:

- evaluating development of Russian legislation regarding the establishment and differentiation of measures of criminal law enforcement;

- studying the criminal laws of foreign countries in terms of determining and regulating various measures of penal actions;

- indicating the basis for division of citizens having committed acts prohibited by criminal law into social groups;

- comparing the goals and features of application of measures, which are the essence of the institutions of criminal liability, punishment and other measures of a criminal law nature;

- analyzing the decisions of the Constitutional Court of Russian Federation on the determination of the content and correlation of categories of criminal liability and punishment;

- conducting a survey of convicts on issues of possibility of their correction and prevention of commission of new crimes due to the application of criminal punishment, as well as on the impact of the length of the term of imprisonment on the process of correction of the convict.

\section{Methods}

The issues of the content and application of various measures of criminal law, determining the essence of criminal liability and its differentiation from criminal punishment have been the subject of numerous scientific studies. So, V.A. Yakushin studied punishment and other measures of influence as independent institutions of Russian criminal law (Tolyatti, 2018) [1]. One of the fundamental studies in Russian legal science, devoted to the consideration of penal actions in general, is the dissertation research by M.V. Bavsuna (Omsk, 2013) [2]. Issues of conditional non-application of criminal punishment to the convicted person were the subject of study of I. Agzamova (Moscow, 2012) [3], and I.A. Tarkhanov investigated the phenomenon of encouragement in the process of implementing criminal liability and applying criminal punishment (Kazan, 2002) [4]. In addition, the modern Russian science of criminal law contains other studies of different years on the stated issues, but, despite this, the problem of differentiating criminal liability, criminal punishment and other measures of a criminal legal nature still remains unresolved.

In the process of conducting this study, various general scientific and private scientific methods of cognition were successively applied. At the initial stage of the study, in assessing the development of Russian criminal legislation on the regulation of the nature and purpose of criminal punishment, criminal liability and other measures of a criminal law nature, as well as decisions of the Constitutional Court of the Russian Federation, the historical and system-structural method of scientific knowledge was applied. 
At the second stage of the study of the provisions of the legislation of foreign countries on the regulation of nature of penal actions in relation to the sane, mentally ill and those lagging behind in the intellectual development of citizens, the comparative legal method was applied. This made it possible to compare similar provisions of the Russian criminal law with the content of the legislation of certain foreign countries on criminal liability and other measures applicable to persons who committed socially dangerous acts.

The third stage of the study is devoted to the study of public opinion regarding the nature and goals of penal actions in its various variations, the goals and results of the application of criminal law measures in relation to persons found guilty of a crime. Here we used the questionnaire and analysis method when processing the data obtained as a result of a survey of 1,096 imprisoned people.

At the final stage, when examining the essence of criminal liability, punishment and other criminal-law measures applicable to various categories of citizens, the dialectic method of cognition was used. The same method, along with the inductive and deductive methods of formal logic, was used to determine the ultimate goals of applying various measures of criminal law to representatives of various categories of convicts, as well as persons whose criminal prosecution is not allowed.

\section{Results}

The study showed that in the Russian criminal law there is no unambiguous understanding of such fundamental legal categories as "criminal liability" and "criminal punishment". The current Criminal Code of Russian Federation (hereinafter CC) is used quite often, but legislator does not establish official grounds for distinguishing them. The lack of a legal definition of criminal liability creates issues with regard to the qualification of certain crimes against justice: bringing a knowingly innocent person to criminal liability (Article 299 of the Criminal Code) and illegal exemption from criminal liability (Article 300 of the Criminal Code).

\section{Discussion}

Unanimity of opinion regarding the exact number of types of measures of criminal law in general among researchers is not observed. An analysis of the research presented in modern criminal law science on the essence of criminal responsibility allows us to conclude that most authors recognize criminal punishment and some "other measures" of a criminal law nature as the main forms of practical implementation, which are included in the scope of legal measures regulated criminal law. However, some researchers insist on a broad understanding of the forms of implementation of criminal liability. So, M.Yu. Dvoretsky refers to such forms as conditional conviction, criminal record, postponement of serving a sentence and some other measures of a criminal law nature [5].

According to V.A. Yakushin, a specific, little-studied, but independent form of implementation of criminal responsibility is the postponement of serving a sentence. Here he includes conditional conviction and coercive measures of educational influence [1]. This opinion finds support at the level of some dissertation studies prepared in the field of the indicated scientific issues [6].

V.V. Pohmelkin suggests recognizing the obligations provided by the threat of sentencing sentence to be served within the framework of probation and postponement of serving a sentence, a compulsory form of criminal responsibility [7]. The author also adds a criminal record to the list of ways to implement criminal liability, since the acts as a kind of residual phenomenon of criminal law enforcement, fixing the results of the punitive- 
educational process and entailing additional legal restrictions for the convicted person. A.A. Shirshov, describes "an instrument of differentiation of criminal responsibility, which is not its specific element" [8].

S.E. Vidmed believes that in addition to punishment, the lead to forms of criminal responsibility includes conditional conviction, exemption from punishment, compulsory medical measures applied to persons with limited liability, compulsory educational measures, criminal record [9].

A similar position is defended by A.V. Shesler, who relates to the forms of realization of the phenomenon under investigation 1) replacement of the unserved part of the criminal punishment with a more severe one in case of evasion of the offender; 2) measures of criminal law enforcement used instead of criminal punishment: conditional conviction, parole, postponement of serving a sentence, compulsory educational measures; 3 ) measures of criminal law coercion, coupled with the execution of punishment: medical coercive measures applied to persons of limited responsibility and release from punishment in connection with a change in the situation (Article 801 of the Criminal Code), as well as in connection with a serious illness (part 2 Article 81 of the Criminal Code), in addition to the mental disorder specified in part 1 of article 81 of the Criminal Code [10].

Thus, based on the given positions of scientists in the field of criminal law, it follows that almost all measures of criminal legal influence to one degree or another can be forms of implementation of criminal liability. Given these circumstances, we can indicate the existence of a formed opinion on the identity of penal actions and criminal liability. The basis of this approach is, obviously, an objective perception of any measure of criminal legal influence: in essence, they all represent deprivation and restriction stipulated by the norms of the criminal law imposed on the person who committed the criminal offense.

It seems that such an undifferentiated approach is quite vulnerable to criticism. The need for a terminological distinction between the listed categories is caused by various goals and conditions for application of a particular measure of penal action. Hence, at the level of the current criminal law, various groups of persons stand out against whom various measures of influence are applied: convicted, insane, socially immature, suffering from drug or other dependence, etc.

Given these circumstances, some researchers, when analyzing the legal nature of criminal liability and other measures of a criminal law nature, rightly pointed out the fundamental difference between these institutions of criminal law.

Already in 1916, in connection with significant innovations in the field of criminal law, proposed by the latest draft criminal codes - Swiss (1908), German (1909), government Austrian (1912), Danish (1912), Serbian (1910), almost the most fundamental in science was the question of the so-called measures of social protection, their essence and distinctive features, making possible to separate from criminal punishment. E. Ya. Nemirovsky, determining their true nature, and deciding whether there is a basis for distinguishing them from punishment pointed out the need to recognize the following fact: new measures are not punishment, but represent an independent, legally separate institution [11].

Based on this, determination of the legal nature of social protection measures becomes a serious issue for the doctrine of criminal law. The opinions of scientists of that time were divided. So, Birkmeyer, Nagler, Beling, feeling the precarious situation, believed that these measures do not apply to criminal law, but represent a field of prevention, an area of administrative law, thereby leaving them no place in the criminal code [2]. A.A. Zhizhilenko adhered to an excellent position not excluding them from the science of criminal law. In his study, he defines five categories that constitute the basis for distinguishing between social protection and punishment measures: 1) a distinction in goals; 2) in external expression; 3) on the basis of application; 4) by its scale; 5) according to the internal content. The scientist assigned special significance to the last three categories 
because of their increased importance. Protection measures, in his opinion, are applied in view of the presence of a person's special mental state, not a guilty act. The commission of an insane act prohibited by criminal law serves as confirmation of this condition and indicates the danger of the individual. Protection measures are addressed to the future of the offender, punishment is addressed to the past. The author insisted that the act was not the only basis for the application of a preventive measure. From this it follows: 1) independence of the measure of protection from a criminal act and from the value of its object; 2) determination of the degree of danger of the offender, characteristics individualization of the realized criminal liability is carried out from. The author pays special attention to the absence of an element of assessment or condemnation in these measures, noting that "from the fact of the appointment of a protective measure in a particular case, we cannot yet conclude that there is a known assessment in this way of the act itself," [12].

Undoubtedly, in the doctrine of criminal law there was another point of view on measures of protection. In particular, punishment and protective measures pursue one goal, defined in the form of the fight against crime through general and private prevention. Protection measures, as well as punishment, provide retribution and put on the legal form of criminal sanction [13].

This opinion seems indisputable. Firstly, if retribution is not presented as meaningless, but to see in it something more than a simple consequence of a known act or condition, if one gives a retribution a normative character, then in medical and preventive measures there is no retribution and there is no negative assessment of personality: they contain stating a certain state of personality, an alien attitude to the due, and they do not express a condemnation of either the disease or its manifestations in the actions of the insane.

Secondly, the idea of a general warning does not allow attributing the insane to criminals, so legal orders, prohibitions and their sanctions can be addressed only to those who are able to understand and follow them, but not to persons deprived of the ability to understand the property and significance of the act and manage their actions due to prolonged or transient mental defects.

E.Ya Nemirovsky was right proposing the separation of punishment and protective measures into two independent institutes of criminal law. He argued that "no matter how hard those and other criminologists try to come up with barriers between the two criminal law institutes, in practice, these barriers collapse, and these measures either replace the punishment or become its continuation" [14]. By the measures of social protection, this scientist understood measures that did not contain an element of conviction, disapproval, which were not necessarily associated with the commission of a criminal act and were different from punishment. An act committed by an insane person cannot be a crime, since it is devoid of a guilty character, but only similar to its last composition.

In the pre-revolutionary period, N. S. Tagantsev also dealt with the issue of distinguishing measures of criminal law influence. He separated the institution of punishment, firstly, from coercive measures taken by public authorities in order to prevent and suppress offenses; secondly, from coercive measures taken by the same authorities with the aim of eliminating difficulties encountered in the administration of justice, in particular, measures taken by a court to implement the procedure established by law; thirdly, from measures that fulfill the role of exclusively compensating for material damage caused to the victim. The scientist classified all measures of a criminal-legal nature into two groups: measures that prevent the onset of harmful consequences or eliminate the consequences that have already come and measures taken in relation to "personalities harmful and dangerous to public order" $[15,16]$.

The picture of the further development of penal institutions and social protection measures in the history of Russian legislation seems quite interesting. So, the first Criminal 
Code of the RSFSR of 1922 included a section called "other measures of social protection" including rules on placement in institutions for the mentally or morally defective; compulsory treatment; the prohibition to hold a particular position or engage in a particular activity or craft; removal from a specific area. Relative to minors between the ages of 14 and 16, measures of medical and pedagogical impact were envisaged [17]. It is obvious that legislator thus eliminated the line between the two independent institutes of penal actions, defining punishment and other measures of social protection as the main, only and whole means of crime. However, a similar legislative approach was implemented in the Criminal Code of the RSFSR in 1926.

A slightly different matter of delineation of the institutions in question was resolved in chap. 6 of the Criminal Code of the RSFSR in 1960, which was devoted to the regulation of coercive measures of a medical and educational nature. Such a decision did not allow equating their measures, applied in the framework of the implementation of criminal liability.

Based on the given retrospective analysis, we see that the institution of measures underwent significant changes unrelated to criminal liability at various stages of development, formation, change of the state. They concerned both its content, purpose, consolidation, legal nature, and the relationship with the institution of punishment.

The Russian Federation is far from the first and not the only state that has established in its criminal law the institution of measures of state influence other than criminal penalties for committing an act prohibited by criminal law. On this basis, the issue of legislative interpretation of criminal law measures in a number of foreign countries is no less interesting. Thus, the Swiss Criminal Code subdivides the criminal law effect on punishment, security measures and other measures (Third Section), thereby blurring the line between these institutions. Article 43 enshrines measures applicable to mentally ill patients: placement of a patient in a medical institution or shelter, internment, outpatient treatment. A separate, different from the one under consideration, the fourth section of the Criminal Code is dedicated to minors, which in turn is divided into separate age groups and measures applied to them: for children (7-15 years old, the first chapter) can be applied: placement in a suitable family or in educational institution); for adolescents (15-18 years old, second chapter) - the same measures, but with the addition of detention up to 14 days or a fine [18].

The Dutch Criminal Code enshrines "punishment" in the second section, and medical and educational measures do not form a separate independent institution, they only have chapters in this section [19].

The French criminal law does not provide for a separate, different from punishment, institution of other measures, although in fact they include security measures that are officially recognized and applied (educational measures applied to minors who have committed socially dangerous acts; medical measures applied to persons recognized as insane due to mental illness, to "dangerous" alcoholics, drug addicts and toxicomaniacs) $[8]$.

A specific, different from punishment, criminal institution of the Criminal Code of Germany are corrective and security measures. Section 3 of the German criminal law identifies two types of legal consequences of a criminal offense: criminal punishment (chap. 1) and measures of correction and safety of the convict, aimed at preventing crime (chap. 6). FRG criminal law means placement in a psychiatric hospital, placement in an isolation facility for alcoholics and drug addicts, preventive detention, supervision, deprivation of permission to drive a motor vehicle, and a ban on the profession. Correction and security measures are not imposed for the crime, but in connection with the crime in cases where it is obvious that the convict himself is a direct or potential public danger. The purpose of such measures is to prevent implementation of this danger, to adjust human behavior, to prevent him from committing new crimes. 
In England, measures of criminal coercion, in addition to punishment, include probation, full or partial exemption from punishment, compulsory treatment and guardianship, supervisory measures applied after exemption from punishment, as well as educational measures for minors [5].

Thus, measures of penal actions, which are different both from punishment and from measures of criminal responsibility in general, are contained in the legislation of the vast majority of countries. However, the analysis of modern criminal laws of foreign countries indicates the terminological diversity of criminal law enforcement measures, a different understanding of their legal nature, which also gives rise to specific features of application in a particular state.

Russian criminal law in this way distinguishes between punishment and other measures of a criminal law nature. However, this "formal differentiation" of penal actions, namely the content of these measures in different chapters, still does not allow establishing the criminal legal independence and certainty of the institutions in question.

Criminal punishment, as well as criminal liability, generally applies only to a person who was found guilty of an offense following a trial or who pleaded guilty at an earlier stage of the criminal proceedings. The use of deprivations and legal restrictions is carried out so that the offender realizes the danger of his criminal behavior and, as a result, does not allow future violations of criminal law regulations. Other measures of a criminal law nature are implemented in relation to persons who, due to mental disorder (insane) or social immaturity (minors) are objectively unable to perceive the public danger and wrongfulness of the committed act. Therefore, other measures of a criminal law nature are appointed and enforced in connection with the commission of a socially dangerous act, with the aim of ridding a person of a mental disorder that excludes sanity, or to ensure the proper education of a teenager who incites a sense of respect for true social values and prevents their violation [11].

Proceeding from this, the distinctive criteria for differentiation of institutes of criminal liability and other measures of a criminal law nature are: 1) ability of a person who has committed an act prohibited by criminal law to be aware of its social danger and wrongfulness; 2) purpose of applying appropriate measures of criminal law.

In the context of criteria for distinguishing between criminal liability and other measures of a criminal law nature that we have identified, certain clarifications must be made regarding the forms of their implementation. As already noted, criminal liability can be realized in the appointment and application of criminal punishment, and, according to some studies, even through a criminal record and conditional conviction.

The conviction of some researchers is regarded as an obsolete criminal law institution, its existence conflicts with the provisions of Art. 6 and 60 of the Criminal Code by the principle of justice and the general principles of sentencing. This issue was the subject of proceedings at the level of the Constitutional Court in 2003. Despite the recognition of the compliance with the Constitution of the Russian Federation of the relevant provisions of the criminal law on criminal records, individual judges formally expressed opinions about the injustice of imposing on a person who has served a criminal sentence in full, additional deprivations and legal restrictions that apply when applying the criminal record [14].

The possibility of recognizing a criminal record as an integral part of criminal liability is due to the presence of common legally relevant features, namely:

- regulation is carried out exclusively by the norms of the criminal law;

- legal content is reduced to deprivations and legal restrictions that apply to the convicted person. They are negative social and legal consequences of the commission of an act prohibited by criminal law;

- implementation is carried out within the period specified by criminal law, its duration is established by a guilty verdict; 
- application is possible only in relation to a person who has not lost the ability to carry out intellectual and volitional activity. The presence of this quality allows the perpetrator to accept the subjective obligation to undergo the deprivations and legal restrictions defined in the Criminal Code that arise after the commission of a crime.

If a criminal record is realized within the framework of criminal liability, which includes deprivation and legal restrictions applicable to a person convicted of a crime, then the legal nature of conditional conviction has not yet been finally determined in the science of criminal law.

Some scholars point to conditional conviction as a form of realization of criminal responsibility or "one of the manifestations of its liberalization" [12]. Other researchers are attempting to identify this criminal-law measure with criminal punishment, since "it corresponds to all the features of this institution or to a "special type of criminal punishment without its actual serving" [18]. Also in criminal law literature, a judgment is made on conditional conviction as a form of exemption from punishment [24].

Conditional conviction was known to the criminal law of our state from the first days of the October Revolution. The first legislative act formalizing conditional conviction was Decree No. 2 of the All-Russian Central Executive Committee of the RSFSR "On the Court" of March 7, 1918. In Art. On Decree 29, it was stated: "lay assessors decide not only on the fact of the crime, but also on the measure of punishment, and they have the right to reduce the punishment prescribed by law, in their opinion, up to a conditional or complete release from any punishment" [17].

The Supreme Court of the RSFSR repeatedly drew attention to the inadmissibility of attributing conditional conviction to punishment, believing that it constitutes exemption from punishment under certain conditions, therefore, conditional conviction cannot be compared with real punishment [1]. The Supreme Court of the Russian Federation separately indicated that "the probationary period established by conditional conviction is not a punishment" [15]. Opponent of classifying conditional conviction as an institution of punishment is Yu.M. Tkachevsky, who rightly drew attention to the logical contradiction when identifying the indicated categories: if the conditional conviction is canceled due to non-fulfillment of the requirements established by the court, the "unfulfilled" part of the conditional conviction should be subject to execution [21]. In this case, the principle of proportionality and justice is implemented, but this fact contradicts Part 3 of Art. 73 of the Criminal Code.

Currently, interpretation of the provisions of Art. 73 of the Criminal Code allows us to assume that the content of conditional conviction is reduced to a special procedure for the execution of certain types of criminal punishments: correctional labor, limitation of military service, detention in a disciplinary military unit and imprisonment for a specific term (here - up to 8 years in prison). In these cases, the court prescribes punishment, and decides to consider this punishment conditional. Accordingly, the sentence imposed on a guilty verdict does not change, and its execution is carried out in specific conditions determined by Art. 73 of the Criminal Code.

The deprivations and legal restrictions imposed by the court on the conditionally convicted person during the probationary period are comparable to deprivations and legal restrictions, which constitute the content of an independent type of criminal punishment in the form of a restriction of freedom. Given this circumstance, some authors express doubts about the possibility of applying conditional conviction in conjunction with restriction of freedom, and also justify the need to exclude punishment from the criminal code in the form of restriction of freedom [9].

It seems that conditional conviction not only duplicates the content of the restriction of freedom creating unjustified competition of the relevant criminal law norms, but also violates the principles of constructing a system of criminal penalties under Art. 44 of the 
Criminal Code. Theoretically, the types of criminal punishment differ from each other in the degree of severity of the negative impact on the convict. However, the systematic construction of those listed in part 1 of article 73 of the Criminal Code of the types of criminal punishment are leveled relative to each other, since correctional labor, and, for example, imprisonment for up to eight years, are not actually executed, as they are considered conditional. The probationary period and the restrictions imposed instead of the actual execution of the criminal punishment may be identical or have slight differences from each other. Therefore, the existence of conditional conviction in the current Criminal Code creates the conditions for violating the principle of justice in the appointment and execution of criminal sentences, and also undermines the foundations of building a system of criminal penalties. It seems that exclusion of the possibility of sentencing will not conditionally lead to a gap in the criminal law, since it already provides for the possibility of applying restrictions on freedom, as well as less severe types of criminal punishment, which do not imply isolation of the convicted person from society. In general, we believe that conditional conviction, due to its procedural nature, cannot be considered as a form of criminal responsibility, since the type of punishment defined in the conviction is not canceled or replaced.

The institute of other measures of a criminal law nature is currently supplemented by such types as confiscation of property and judicial fine. Unlike coercive measures of a medical nature and coercive measures of educational influence, these "other measures" are applied to persons who committed crimes (judicial fine), as well as those found guilty of a crime (confiscation of property). Given these circumstances, confiscation of property, which in accordance with Part 1 of Art. 1041 of the Criminal Code, applied on the basis of a guilty verdict of the court, should be recognized as one of the measures for the implementation of criminal liability, or rather, the criminal punishment, which it was until December 2003.

A judicial fine, defined simultaneously as a type of other measures of a criminal legal nature, and as a specific type of exemption from criminal liability (Article 762 of the Criminal Code), in addition to the punitive element, includes criminal law incentives in its content. For this reason, it cannot be recognized as either a form of criminal liability or a "different measure" of a criminal law nature.

Finally, the current criminal law, regulating the penal actions includes a number of incentive norms that determine the basis and procedure for exemption from criminal punishment [20]. Such should be recognized as measures taken in relation to the person who committed the crime, the amount of deprivation and legal restrictions of which was significantly reduced due to the establishment of the fact of positive post-criminal behavior of the person. Here we can talk about measures whose application is covered by the institution of exemption from punishment: parole (Article 79 of the Criminal Code), replacing the unserved part of the sentence with a milder type of punishment (Article 80 of the Criminal Code), etc. These measures are also included in the scope of criminal liability, however, are characterized by a combination of punitive and incentive effects on the convict.

This position is confirmed by a survey of 1,096 convicted citizens serving sentences of imprisonment in the Central Federal District of Russia. So, $85 \%$ of respondents believe that they will be kept from committing crimes and other offenses, especially during the probationary period with conditional early release from the assigned punishment. This is due to the fear of canceling parole and the possibility of applying more stringent forms of criminal responsibility. $95 \%$ of the convicted respondents believe that fear of stricter criminal punishment is the main incentive for law-abiding behavior of citizens who have served their sentences in prison. 


\section{Conclusion}

Both in the implementation of criminal liability and other measures of a criminal-legal nature, and in the case of a penal action provided for by incentive criminal law, deprivations and legal restrictions are applied to the person who committed the criminal offense. However, a distinctive feature of the types of the group identified by us is a significant mitigation of the criminal law impact that applies to the criminal.

These measures are included in the total amount of criminal liability, but the decrease in the degree of punitive retribution is caused by the fact that the offender has taken actions that significantly reduce the public danger of his personality.

The essence of the criminal law measures in this case does not change and represents the same deprivations and legal restrictions applied in accordance with applicable law to a person convicted of a crime. Therefore, the separation of these measures from the total amount of criminal liability into an independent group of penal actions is unacceptable. At the same time, the possibility of their implementation on special conditions to reduce the public danger of an individual indicates the need to distinguish between criminal liability measures applied on a common basis.

Hence, deprivation and legal restrictions constituting the essence of criminal liability are realized by forcing the convicted person to perform various duties during the term:

- the unserved part of the sentence upon parole (parts 1 and 2 of article 79 of the Criminal Code);

- execution of a milder type of punishment imposed by replacing the measure of state coercion originally defined in the conviction (part 1 of article 80 of the Criminal Code);

- countable until the child reaches the age of 14 (part 1 of article 82 of the Criminal Code);

- necessary for voluntary treatment of drug addiction, medical and (or) social rehabilitation (part 1 of article 821 of the Criminal Code).

Given these circumstances, the judicial fine, currently officially recognized as one of the "other measures" of a criminal law nature, should in fact be attributed to the group of criminal liability measures that are assigned and implemented in accordance with encouraging criminal law norms.

Criminal law enforcement is ensured by the application of criminal liability measures and other measures of a criminal law nature. In turn, criminal liability is implemented on general and preferential terms. In the first case, criminal liability is realized through the application of criminal punishment and criminal record, while the conditional conviction of the person who committed the crime cannot be recognized as an independent measure of criminal responsibility, as well as penal action in general.

On preferential terms, criminal liability is realized when the person who committed the crime is deprived of his deprivations and legal rights, which are the essence of certain types of exemption from criminal punishment. The judicial penalty should also be included in the same group of measures, since all the legally significant signs of the institution of exemption from criminal punishment are inherent in it.

The basis for applying state coercion measures provided for by the encouraging norms of domestic criminal legislation is the fact of positive post-criminal behavior significantly reducing the social danger of the perpetrator.

The authors express their deep gratitude to the leadership of the Academy of the Federal Penitentiary Service of Russia for the help and support provided in the conduct of this study. 


\section{References}

1. I. M. Agzamov Conditional non-use of punishment in the criminal law of Russia: monograph, (2012)

2. M. V. Bavsun Bull. Volgogr. Acad. Ministr. Intern. Af. Rus. 38-46 (2017)

3. M. Yu. Butler, Bull. Econ. Secur. 90-95, (2016)

4. V. S. Egorov, Issues of legal regulation of measures of criminal coercion, (2006)

5. S.A. Korneev, Criminal law measures not related to criminal liability // Jurisprudence and law enforcement practice. 2019. №3. P. 64-72.

6. S. A. Laptev, Crim. Execut. Syst. Law, Econ. Manag. 12-18 (2013).

7. V. F. Lapshin, Bull. Instit. Crim. Punish. Correct. 74-75 (2007)

8. B.Z. Malikov, Conditional conviction - a form of conditional punishment // Institute Herald: crime, punishment, correction. 2012. No2. P. 14-18.

9. Yu. M. Tkachevsky, Selected Works (2010)

10. A. V. Shesler, Bull. Vladimir Law Instit. 116-121 (2018)

11. V.A. Yakushin, Punishment and other measures of criminal law influence: Monograph. (2018)

12. V. Lez'Er, N. Semerianova, A. Kopytova, Y. Truntsevsky, E3S Web of Conferences 110,02093 (2019), DOI: 10.1051/e3sconf/201911002093

13. A.V. Kopytova, N.S. Zotkina, I.G. Reshetnikova, MATEC Web of Conferences 239, 04012 (2018) DOI: 10.1051/matecconf/201823904012

14. Lez'Er, V., Semeryanova, N., Kopytova, A., Kvach, I. E3S Web of Conferences 110, 02094 (2019), DOI: 10.1051/e3sconf/201911002094

15. R. Kolobov, U. Filatova, V. Borshcheniuk, N. Semerianova, D. Bayanov, E3S Web of Conferences 110, 02095 (2019), DOI: 10.1051/e3sconf/201911002095

16. Y.V. Truntsevsky, I.I. Lukiny, A.V. Sumachev, A.V. Kopytova, MATEC Web of Conferences 170, 01067 (2018) DOI: 10.1051/matecconf/201817001067

17. A. Kopytova, MATEC Web of Conferences 106, 08056 (2017) DOI: $10.1051 /$ matecconf/201710608056

18. U. Filatova, N. Semeryanova, S. Suslova, A. Gabudina, A. Kopytova, E3S Web of Conferences 91,08071 (2019), DOI: 10.1051/e3sconf/20199108071

19. N. Semeryanova, O. Fedorenko, A. Kopytova, MATEC Web of Conferences 239,04013 (2018), DOI: 10.1051/matecconf/201823904013

20. V. Akberdina, L. Pushkareva, 4th International Conference on Social, Business, and Academic Leadership, 9-14 (Paris, Atlantis Press 2019). 